\title{
Knowledge, Attitudes, Behavior and their impact on Vitamin D Status among Undergraduate University Female Students
}

\author{
Dina IS ${ }^{1}$, Afaf $\mathrm{HS}^{2}$, Nefisa $\mathrm{HB}^{\mathbf{2}}$, and Mohamed $\mathrm{MN}^{\mathbf{3}}$ \\ ${ }^{I}$ Department of Clinical Nutrition; National Nutrition Institute, Cairo, Egypt \\ ${ }^{2}$ Department of Nutrition and Food science; Faculty of Home Economics; Helwan \\ University, Egypt. \\ ${ }^{3}$ Ph.D. Student, Department of Nutrition and Food science; Faculty of Home \\ Economics; Helwan University, Egypt.
}

\section{ABSTRACT}

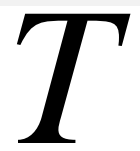

he research was carried out to study the effect of some personal, behavioral, and environmental factors on vitamin $D$ level amonguniversity female undergraduates in Egypt.A convenient sample consisted of125 first grade Egyptianuniversity female youth was selected. Written consentswerean initial basic step. They filled aknowledge, attitudes, and practice (KAP) pre-structured questionnaire and were subjected to dietary assessmentusing 24 hours recall, frequencypattern, and milk consumption sheets. Laboratory evaluation of vitamin $D$ and related indicators were measured. Food intake was analyzed and compared to the recommended dietary allowances using the food composition table of the National Nutrition Institute and based on WHO/FAO recommendations. Resultsrevealed that majority of respondents (96.0\%) were veiled and $88.0 \%$ were exposed to sun at noon time. Face and hands were the exposed parts in $96.0 \%$ of responses and $56.0 \%$ mentioned that sun-exposure took more than an hour. Exposure to pesticides was mentioned in $16.0 \%$ of responses. Nearly two thirds were exposed to sun while windows were closed. Only $22.0 \%$ heard about vitamin $D$ and two thirds considered milk among un-favored food items. This study concluded that to track progress toward getting rid of a health problem, we have to raise the level of awareness of youth and young adults about this problem.This study emphasized the need for further vitamin $D$ assessment and interventions targeted at all people. There is an urgent need for public education about the vital role of vitamin $D$ to improve vitamin $D$-related practice and to minimize the complications of its deficiency.

Key words: Vitamin D awareness-Female Adolescent -University undergraduate. 
INTRODUCTION:

The general physiological function of vitamin $\mathrm{D}$ (VD) is to keep us healthy by promoting strong bones, properly functioning muscles and a potent immune system. When weather and season allows, we can keep our vitamin D levels up through the endogenous production during carefully dosed exposure to sunlight(Carlberg 2014).UVB rays are present only during mid-day at higher latitudes and do not penetrate clouds. The time needed to produce adequate vitamin $\mathrm{D}$ from the skin depends on the strength of the UVB rays (i.e., place of residence), the length of time spent in the sun, and the amount of pigment in the skin(Kulie, et al., 2009).

Sunlight is strong throughout year in Egypt which should be sufficient for skin to manufacture the vitamin. However, many females of the population are veiled, commonly covering their whole body except the face, hands, and feet; therefore, many females may not be exposed to sufficient amounts of sunlight (Botros, 2015). In addition, the level of air pollution is negatively associated to the amount of solar UVB that reaches earth surface, as a result, more pollutant areas, less UVB passage and consequently, $25(\mathrm{OH})$ vitamin $\mathrm{D}$ cutaneous syntheses reduces (Hossein-panah, et al., 2010).

\section{SUBJECTS \& METHODS}

The research was carried out to study the effect of some personal, behavioral, and environmental factors on vitamin D level among Egyptian university female undergraduates.

\section{Subjects:}

A convenient sample was selected covering 3 seasons; autumn, winter, and spring, and consisted of 125 apparently healthy Egyptian first grade university female youth. A written consent was an initial basic step. They were subjected to:

\section{Methods:}


Knowledge, Attitudes, and Behavior (KAP) and their impact on Vitamin D Status among Undergraduate University Female Students

Dina IS, Afaf HS, Nefisa HB, and Mohamed MN

A KAP (Knowledge, attitudes, and practice) prestructured questionnaire was designed to assess vitamin Drelated knowledge, dietary attitudes, and actual vitamin Drelated practice among 125 undergraduate female adolescents. They were conveniently selected among those attending Helwan University.

\section{Laboratory indicators}

Laboratory analysis were measured using (Stanbio Total Calcium Liquicolor, Procedure No 0150) for calcium (Ca) (Sarkar and Chauhan, 1967), (Bio Med - phosphorous (PH123100)) for phosphorus (P) (Vassault, 1989), and (DRGDEA) Kinetic method for alkaline phosphates (ALP) (Tiets, (1995). All previous tests were done using spectrometric device (Kenza, France). Serum 25-OH vitamin D was done by DRG ELISA (Houghton and Vieth, 2006) LOT: 80k035 Cat .Nr:EIA5396 and Serum Parathyroid hormone (PTH) was done by immune- enzymatic assay (HPTH-ASIA) Cat NO.: kAP1481 (Martin, 1979). Blood samples were delivered to the National Nutrition Institute (NNI) labs for testing.

\section{Dietary assessment}

Dietary assessmentwas done using 24 hours dietary recall, frequency pattern, and milk consumption sheets.Food intake was compared to the recommended dietary allowances using the food composition table of the National Nutrition Institute and based on WHO/FAO recommendations (NNI, 2006) (FAO/WHO/NUN, 2004).

\section{RESULTS:}

Table (1) showed that $74.0 \%$ of female college had low vitamin D levels; either in the deficient or in the insufficient range. Serum PTH was high in $22.0 \%$ and low serum calcium was present in $45.0 \%$. Serum alkaline phosphatase was in the normal range and $47.5 \%$ had high serum phosphorus level. However fasting was optional 
Dina IS, Afaf HS, Nefisa HB, and Mohamed MN

and blood samples were collected at different times in relation tolast eaten meal.

Based on Cut-offs of VD, PTH, and Calcium Simultaneously (vitamin D metabolic status); 11 (26.0\%) of participants; in the spring sample, were considered deficient/or insufficient in their VD and 15 (36.0\%) were considered as having normal levels (sufficient). As for the autumn sample, 8 (14.0\%) were deficient/ or insufficient and 42 (71.0\%) had normal VD values.

\section{Vitamin D-related knowledge and actual practice:}

One of the principal indicators for tracking progress toward getting rid of a health problem is the extent to which youth and young adults have comprehensive correct knowledge of that problem. Exploring vitamin D related practices showed that:

Majority of respondents $89.0 \%$ were exposed to sun and did that at the optimum time (around 12 o'clock). Face and hands were the parts exposed in $96.0 \%$ of responses and $59.0 \%$ mentioned that the exposure took more than an hour. Exposure to pesticides was mentioned in $20.0 \%$ of response. Nearly two third of adolescent females were exposed to sun at their homes while windows were closed.

Table (4) showed frequency distribution of participants by some vitamin Drelated knowledge. The level of awareness about vitamin D was low as only 27 university graduates out of 125 (22.0\%) had some previous knowledge about vitamin D. Among respondents who had heard about vitamin D (27 students), 24 related the importance of vitamin $\mathrm{D}$ for bone health, 18 knew that sun-exposure had a relation to vitamin $\mathrm{D}$ and mentioned sun-rays as being the best source for the vitamin ever. Only 7 respondents thought that daily food intake was sufficient enough to give our needs from vitamin $\mathrm{D}$ but nearly none was knowledgeable about vitamin D content in various milk forms. 
Knowledge, Attitudes, and Behavior (KAP) and their impact on Vitamin D Status among Undergraduate University Female Students

Dina IS, Afaf HS, Nefisa HB, and Mohamed MN

Majority thought that vitamin D is prevalent among girls but only 18 were able to give an explanation. Following the nutrition education session, participant females were able to give correct responses.

\section{Vitamin D-related Dietary} practices:

Nearly all student females $(90.0 \%)$, consumed milk just once per day and two thirds considered milk among the un-preferred food items and anotherone third considered milk a costly food item.

Based on WHO recommendations (2006), the analysis of previous 24 hours before interview reflected the marked shortage in daily energy intake among respondents as reflected by the median value for energy consumption regardless of number of calcium services. Three quarters of student females were receiving below the recommendation of 2200 kcal daily.

Only half of participants who received 3 servings of calcium had their energy recommendations fulfilled. In contrast, protein intake was nearly $\quad 127.0 \% \quad$ of recommendation on average and a source of $12.8 \%$ of total energy per day. Consumption of calcium rich products with every meal ensures that requirements are met for calcium and phosphorus, and other minerals needed for bone health(Peters, et al., 2012)

In contrast to the accepted average intake of phosphorus, average calcium in diet was significantly less than daily recommendation of $1300 \mathrm{mg}$ daily (FAO/WHO,2004)even among the group who consumed 3 calcium services. Calcium to phosphorus ratio in diet was almost reversed and this was related to increased consumption of high-phosphorus containing food items as legumes, processed cheese as well as soft drinks.Magnesium in diet was also less than WHO/FAO recommendations of $230 \mathrm{mg}$ per day.

The average dietary 
Dina IS, Afaf HS, Nefisa HB, and Mohamed MN

intakes of iron was inadequate if compared to WHO/FAO recommendations of $29-31 \mathrm{mg}$ and $25.0 \%$ of respondents had zinc intake below the recommendation of $8 \mathrm{mg}$ per day provided that diet composition was of moderate bioavailability for both of them.

Table (7) showed Spearman nonparametric - correlation between Vitamin D status groups and some risky Factors: a very significant correlation between vitamin $\mathrm{D}$ metabolic state and season of the year. Vitamin D sufficient level is more likely to be achieved in autumn more than in spring and this could be explained by more exposure to sun in autumn compared to spring where hot weather in spring could limit sun exposure.

Results showed also an important trend between frequency of fish consumption and vitamin $\mathrm{D}$ state. The more the consumption of fish, the more likely is the achievement of normal vitamin D state. On the other hand, frequency of consumption of calcium food sources did not show any significant correlation with vitamin D state. This study showed that the main predictor of low vitamin D status was seasons of the year.

\section{DISCUSSION:}

This study raised a health concern for the Egyptian population in general. If healthy adolescents, living in a country with abundant sunshine, specializing different fields including the pharmacy college have this lack of knowledge about vitamin D deficiency, what can we say about the situation among the Egyptian community overall? One of the principal indicators for tracking progress toward getting rid of a health problem is the extent to which youth and young adults have comprehensive correct knowledge of that problem. University students and particularly Pharmacists have the capacity to use their unique perspective concerning drug therapy and collaborate in a multidisciplinary approach to monitor and optimize vitamin D 
supplementation in all patients, especially those who are at high risk.

\section{Concerning vitamin D} related practice; determinants that influence the synthesis of 25 $(\mathrm{OH})$ vitamin $\mathrm{D}$ in the skin as exposure to UVB solar radiation, the strength of the UVB rays (place of residence), the length of time spent in the sun, skin hue, sun-screen use, and being indoors(Tsiaras and Weinstock, 2011) (Report of the Independent Advisory Group on Non-ionising Radiation, 2017)did not show their effects on vitamin D level among college females as $96.0 \%$ were veiled and two-thirds had dark skin-hue and may not be exposed to sufficient amounts of sunlight. Results also showed that nearly two thirds of participated females were exposed to sun while windows were closed and it is evidenced that UVBrays do not penetrate clouds or closed windows ${ }^{2}$. Other factors were nearly equivocal in University Hostelsituation. The only variation in serum vitamin D showed in this study was due to season of the year.

Natural dietary sources of $25(\mathrm{OH}$ vitamin $\mathrm{D}$ are very few and foods that are fortified with $25(\mathrm{OH})$ vitamin $\mathrm{D}$ are often inadequate to satisfy either a child's or an adult's $25(\mathrm{OH})$ vitamin $\mathrm{D}$ requirement(Calvo, et al., 2005). On the other hand, adolescence is critical ages to skeletal growth and reach to optimal peak bone mass. The enough intake of calcium and $25(\mathrm{OH}) \mathrm{D}_{3}$ from the diet, and the achievement of normal serum range of calcium and $25(\mathrm{OH})$ $\mathrm{D}_{3}$; have positive effects on bone in adolescents. Milk consumption positively correlates with bone mineral density of the total body, spine and radius in adolescent girls (Peters, et al., 2012). Unfortunately, nearly all college females $(90.0 \%)$, consumed milk just once per day. Two thirds mentioned milk among the un-preferred food items and another one third considered milk a costly food item.

Although, non- 
Dina IS, Afaf HS, Nefisa HB, and Mohamed MN

parametric correlation between vitamin $\mathrm{D}$ metabolic status and frequency of food items' intake was not statistically significant, yet it showed a positive trend between frequent fish consumption and VD status.

In theory, consuming calcium-rich foods such as bones, fermented dairy (e.g., unsweetened yogurt, kefir, and cheese), leafy greens, almonds, and chia seeds may be an effective strategy for improving both calcium intake and longterm health.

Apart from milk fortification; vitamin D fortification is still not used to reach the needed levels for vitamin $D$ intake in Egypt. Considering the abovementioned results that two thirds of college females mentioned milk among the un-preferred food items and another one third considered milk a costly food item, so, it is needed to increase vitamin $\mathrm{D}$ fortification of staples, such as grain products, include pasta, bread, and other baked goods that are frequently consumed by the general population and could be the greatest source of vitamin D for all age, gender, and racial groups,

Dietary supplement use is another option for improving vitamin $\mathrm{D}$ status. Dietary supplements are allowed to contain up to the tolerable upper limit (2000 IU or 50mg) as designated by the 1997 Dietary Reference Intakes(Calvo, et al., 2005). The introduction of more a novel dietary supplement product as fruit drinks or chocolate candy can lower the barrier to obtaining adequate vitamin $\mathrm{D}$ intake for many individuals and suggests a new approach to providing products that are custom designed to the tastes and needs of a specific target population.

\section{CONCLUSION}

In conclusion the cost to fortify food with vitamin D or to increase supplement potency is relatively inexpensive compared with the cost of developing drug treatments for the many chronic 
Knowledge, Attitudes, and Behavior (KAP) and their impact on Vitamin D Status among Undergraduate University Female Students

Dina IS, Afaf HS, Nefisa HB, and Mohamed MN

diseases strongly associated with vitamin $\mathrm{D}$ insufficiency. In the case of maintaining optimal vitamin D status, an ounce of prevention may very well be worth a pound of cure.

\section{RECOMMENDATIONS}

There is an urge need to increase the awareness among people about the importance of sun exposure as the main source of vitamin $\mathrm{D}$ and about the healthy diet rich in vitamin D. Dietary fortification of a staple food with calcium and vitamin D is clearly effective in reaching the general population. Further researches and intervention regarding vitamin $\mathrm{D}$ could with an emphasis on measuring serum $25(\mathrm{OH}) \mathrm{D}$ concentrations in adolescents who are at risk for vitamin $\mathrm{D}$ deficiency or insufficiency.

\section{REFERENCES:}

Botros RM; Sabry

IM; Abdelbaky RS; Eid YM; Nasr MS and Hendawy LM (2015):
Vitamin D deficiency among healthy Egyptian females Endocrinol. Nutr. ; 62(7):314- 21.

Calvo MS; Whiting SJ and Barton CN (2005):

Vitamin D Intake: A Global Perspective of Current Status. American Society for Nutritional Sciences J. Nutrition 31016.

\section{Carlberg C (2014):}

The physiology of vitaminD - far more than calcium and bone. Front. Physiol. September (5):335.

FAO/WHO/UNU (2004):

United Nations University, World Health Organization, Food and Agriculture Organization Rome, 2004 Human vitamin and mineral requirements, Report of a Joint FAO/WHO Human energy requirements Report of a Joint FAO/WHO/UNU Expert 
Knowledge, Attitudes, and Behavior (KAP) and their impact on Vitamin D Status among Undergraduate University Female Students

Dina IS, Afaf HS, Nefisa HB, and Mohamed MN

Consultation.

Hossein-panah F; Sima H; Heibatollahi M; Moghbel N; Asefzade $S$ andAzizi $F$ (2010):

The effects of air pollution on vitamin $\mathrm{D}$ status in healthy women: a cross sectional study. BMC Public Health. 10:519.

Houghton LA and Vieth $R$ (2006):

The case against ergocalciferol (vitamin D2) as a vitamin supplement .Am.J.Nutr., :84,694-97.

Kulie T, Groff A, Redmer J, HounshellJ and Schrager $S$ (2009):

Vitamin D: An

Evidence-Based Review.

J Am Board Fam Med ;22:698 -706.

Martin KJ, Hruska kA, and Freitag J (1979):

The Peripheral metabolism of parathyroid
New Engl.Med

,:30120:1092.

NNI (2006):

National Nutrition Institute food composition table.

Peters B, Verly Jr E, Marchioni D, Fisberg $\mathbf{M}$, Martini L.(2012):

The influence of breakfast and dairy products on dietary calcium and vitamin D intake in postpubertal adolescents and young adults.J Hum Nutr Diet.; 25:69-74.

Report of a joint WHO/FAO/UNU Expert Consultation (2007):

Protein and amino acid requirements in human nutrition, Technical Report Series, No 935.

Report of the independent Advisory Group on NonionisingRadiation (2017):

Ultraviolet Radiation, Vitamin D and Health.RCE-30 
Knowledge, Attitudes, and Behavior (KAP) and their impact on Vitamin D Status among Undergraduate University Female Students

Dina IS, Afaf HS, Nefisa HB, and Mohamed MN

Sarkar BR, and Chauhan UPS (1967):

A new method for determining micro quantities of calcium in biological

materials. Analytical biochemistry, 20(1), 155166.

Tiets NW (1995):

Clinical Guide to Laboratory Tests $3^{\text {rd }}$ edition.W.B. Saunders, Co., Philadelphia, PA.

\section{Tsiaras WG, Weinstock MA} (2011):

Factors influencing vitamin D status ,Acta Derm Venereol.; 91:115-24.

Vassault A, Young DS, Kaplan LA, et al (1989):

Effects of pre analytical variables on clinical laboratory tests, Ann, Bio, Clin.44, 686.

WHO (2006):

Adolescent Nutrition; A Review of the Situation in Selected South-East Asian Countries.SEANUT-163 
Knowledge, Attitudes, and Behavior (KAP) and their impact on Vitamin D Status among Undergraduate University Female Students

Dina IS, Afaf HS, Nefisa HB, and Mohamed MN

Table (1): Cut-offs of Lab Indicators Used in the Study

\begin{tabular}{|c|c|c|c|c|}
\hline \multirow[t]{2}{*}{ Indicator } & \multirow[t]{2}{*}{ Cut offs } & \multirow[t]{2}{*}{ Reference } & \multicolumn{2}{|c|}{ Outcome } \\
\hline & & & $\begin{array}{l}\text { No (120) } \\
*\end{array}$ & $\%$ \\
\hline $\begin{array}{l}\text { PTH } \\
\text { hypo- } \\
\text { parathyroidism } \\
\text { Insufficiency } \\
\text { Normal } \\
\text { pre-hyper- } \\
\text { parathyroidism } \\
\text { hyperparathyroidis } \\
\text { m }\end{array}$ & $\begin{array}{l}\text { 0-6.4 } \quad \mathrm{pg} / \mathrm{ml} \\
\begin{array}{ll}\text { > } 6.4-15.9 & \mathrm{pg} / \mathrm{ml} \\
16-46 & \mathrm{pg} / \mathrm{ml} \\
47-106 & \mathrm{pg} / \mathrm{ml} \\
& \\
>106 \quad \mathrm{pg} / \mathrm{ml}\end{array}\end{array}$ & Martin, 1979 & $\begin{array}{r}- \\
9 \\
84 \\
26 \\
\\
1\end{array}$ & $\begin{array}{c}0.0 \\
\\
0.09 \\
70.0 \\
22.0 \\
\\
0.01\end{array}$ \\
\hline $\begin{array}{lr}\text { Vitamin D } & \\
\text { Deficiency } & \text { VDD } \\
\text { Insufficiency } & \text { VDI } \\
\text { Sufficiency } & \text { VDS } \\
\text { toxicity } & \\
\end{array}$ & $\begin{array}{l}<10 \mathrm{ng} / \mathrm{ml} \\
10-29 \mathrm{ng} / \mathrm{ml} \\
30-100 \mathrm{ng} / \mathrm{ml} \\
>100 \mathrm{ng} / \mathrm{ml}\end{array}$ & $\begin{array}{l}\text { Houghton, } \\
2006\end{array}$ & $\begin{array}{l}12 \\
77 \\
31 \\
---\end{array}$ & $\begin{array}{r}10.0 \\
64.0 \\
26.0 \\
0.0\end{array}$ \\
\hline $\begin{array}{l}\text { Calcium } \\
\text { Hypo calcemia } \\
\text { Normal } \\
\text { Hyper calcemia }\end{array}$ & $\begin{array}{l}<9.2 \mathrm{mg} / \mathrm{dl} \\
9.2-11.0 \mathrm{mg} / \mathrm{dl} \\
>11.0 \mathrm{mg} / \mathrm{dl}\end{array}$ & $\begin{array}{l}\text { Sarkar and } \\
\text { Chauhan, } \\
1967\end{array}$ & $\begin{array}{r}54 \\
59 \\
7\end{array}$ & $\begin{array}{r}45.0 \\
49.0 \\
6.0\end{array}$ \\
\hline $\begin{array}{l}\text { Phosphorus } \\
\text { Hypo phosphatemia } \\
\text { Normal } \\
\text { Hyper phosphatemia }\end{array}$ & $\begin{array}{l}<2.7 \mathrm{mg} / \mathrm{dl} \\
2.7-4.5 \mathrm{mg} / \mathrm{dl} \\
>4.5 \mathrm{mg} / \mathrm{dl}\end{array}$ & $\begin{array}{l}\text { Vassault, } \\
1989\end{array}$ & $\begin{array}{l}-- \\
63 \\
57\end{array}$ & $\begin{array}{r}0.0 \\
52.5 \\
47.5\end{array}$ \\
\hline Alkaline Phosphatase & Up to $270 \mathrm{U} / \mathrm{L}$ & Tiets, 1995 & 120 & 100.0 \\
\hline
\end{tabular}

- 120 out of 125 female participants had valid lab indicators 
Knowledge, Attitudes, and Behavior (KAP) and their impact on Vitamin D Status among Undergraduate University Female Students

Dina IS, Afaf HS, Nefisa HB, and Mohamed MN

Table (2): Frequency Distribution of Participants by their Vitamin D Status* per Season

\begin{tabular}{|c|c|c|c|c|c|c|c|c|c|}
\hline \multirow[t]{2}{*}{ Season } & \multicolumn{6}{|c|}{ Vitamin D metabolic status } & \multirow{2}{*}{\multicolumn{2}{|c|}{$\begin{array}{l}\text { Total } \\
(120)\end{array}$}} & \multirow{2}{*}{$\begin{array}{c}\text { Chi } \\
\text { square }\end{array}$} \\
\hline & & VDI & & lcemia & & & & & \\
\hline Winter & 3 & 37.0 & 1 & 13.0 & 4 & 50.0 & 8 & 6.0 & .006 \\
\hline Autumn & 8 & 14.0 & 9 & 15.0 & 42 & 71.0 & 59 & 49.0 & .006 \\
\hline Spring & 11 & 26.0 & 16 & 38.0 & 15 & 36.0 & 42 & 35.0 & .068 \\
\hline
\end{tabular}

*Vitamin D Status is the classification of laboratory results based on the normal physiological PTH-VD axis using cut-offs of vitamin D, calcium, and phosphorus in relation to cut-offs of $P T H . V D D=V D$ deficient $V D I=V D$ insufficient $V D S=V D$ sufficient 
Knowledge, Attitudes, and Behavior (KAP) and their impact on Vitamin D Status among Undergraduate University Female Students

Dina IS, Afaf HS, Nefisa HB, and Mohamed MN

Table (3): Frequency Distribution of Participants by their Vitamin D Status* and some Vitamin D- related Practices:

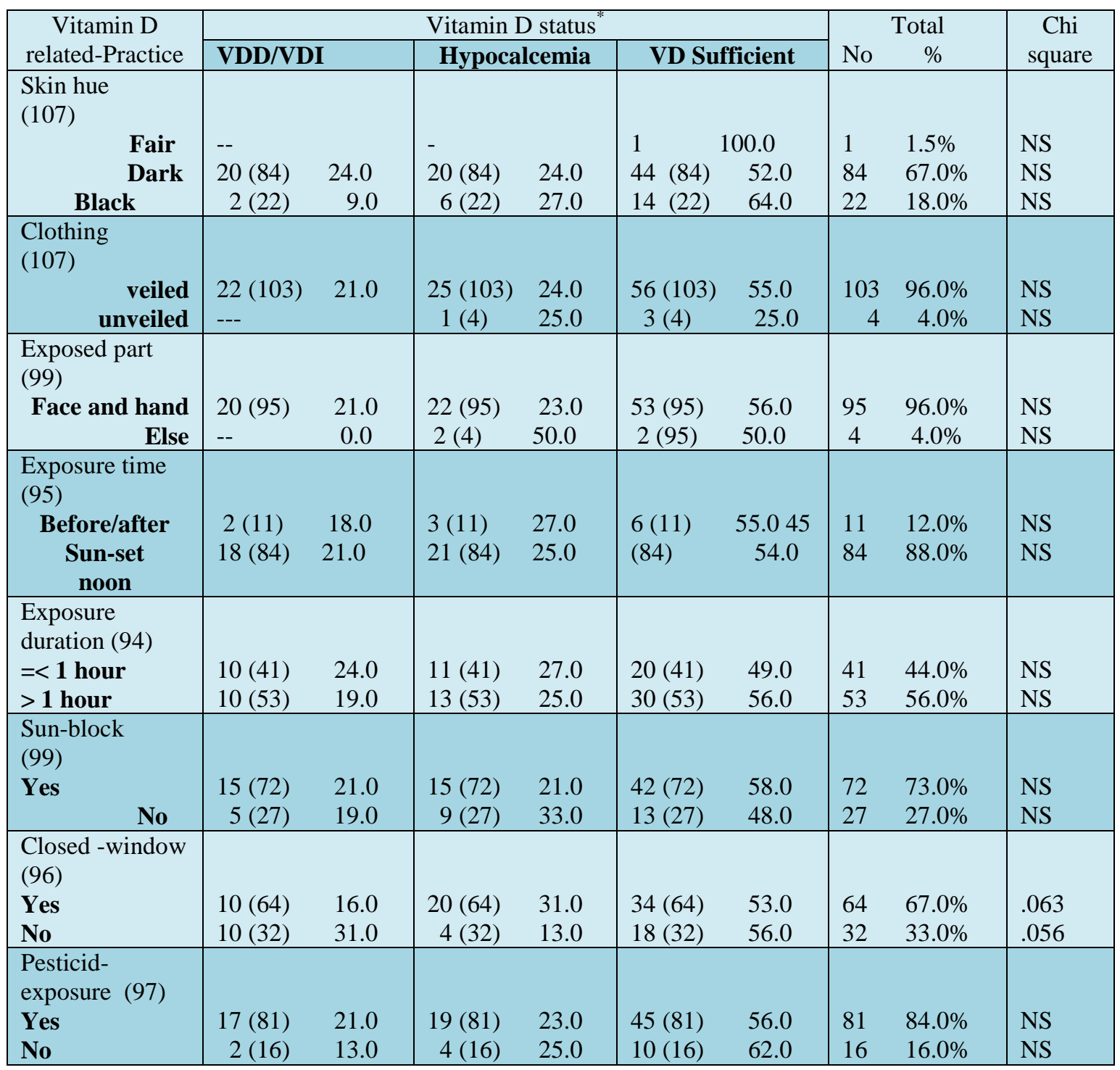

*Vitamin D Status is the classification of laboratory results based on the normal physiological PTH-VD axis using cut-offs of vitamin D, calcium, and phosphorus in relation to cut-offs of PTH. 
Knowledge, Attitudes, and Behavior (KAP) and their impact on Vitamin D Status among Undergraduate University Female Students

Dina IS, Afaf HS, Nefisa HB, and Mohamed MN

Table (4): Frequency Distribution of Participants by some Vitamin Drelated Knowledge:

\begin{tabular}{|c|c|c|c|c|}
\hline \multirow[t]{2}{*}{ Vitamin D -related Knowledge } & \multicolumn{2}{|c|}{$\begin{array}{c}\text { Pre-test response } \\
(27)\end{array}$} & \multicolumn{2}{|c|}{$\begin{array}{c}\text { Post-test response } \\
(125)\end{array}$} \\
\hline & No & $\%$ & No & $\%$ \\
\hline $\begin{array}{c}\text { Have you ever heard about vitamin D? } \\
\text { Yes } \\
\text { No }\end{array}$ & $\begin{array}{l}27 \\
98\end{array}$ & $\begin{array}{l}22.0 \\
78.0\end{array}$ & $\begin{array}{c}125 \\
0\end{array}$ & $\begin{array}{r}100.0 \\
0.0\end{array}$ \\
\hline $\begin{array}{c}\text { What is the importance of vitamin D? } \\
\text { Bone integrity } \\
\text { Prevents anemia }\end{array}$ & $\begin{array}{r}24 \\
0\end{array}$ & $\begin{array}{c}90.0 \\
0.0\end{array}$ & $\begin{array}{c}123 \\
2\end{array}$ & $\begin{array}{c}99.0 \\
1.0\end{array}$ \\
\hline $\begin{array}{l}\text { Which is the } \frac{\text { main }}{\text { Sun ray }} \\
\text { Fish }\end{array}$ & $\begin{array}{r}18 \\
6\end{array}$ & $\begin{array}{l}70.0 \\
20.0\end{array}$ & $\begin{array}{l}89 \\
36\end{array}$ & $\begin{array}{l}70.9 \\
29.1\end{array}$ \\
\hline $\begin{array}{c}\text { Dose Vitamin D has any relation to Sun? } \\
\text { Yes } \\
\text { No }\end{array}$ & $\begin{array}{r}18 \\
0\end{array}$ & $\begin{array}{c}70.0 \\
0.0\end{array}$ & $\begin{array}{c}125 \\
0\end{array}$ & $\begin{array}{c}100.0 \\
0.0\end{array}$ \\
\hline $\begin{array}{c}\text { Is Vitamin D sufficient in food? } \\
\text { Yes } \\
\text { No } \\
\end{array}$ & $\begin{array}{r}7 \\
14 \\
\end{array}$ & $\begin{array}{l}24.3 \\
53.4\end{array}$ & $\begin{array}{l}86 \\
38 \\
\end{array}$ & $\begin{array}{l}68.4 \\
30.6 \\
\end{array}$ \\
\hline $\begin{array}{l}\text { Which is better as a Vitamin Dsource; } \\
\text { Powder milk } \\
\text { Fluid Milk } \\
\text { Both are equal }\end{array}$ & $\begin{array}{c}3 \\
21 \\
3\end{array}$ & $\begin{array}{l}10.2 \\
80.1 \\
10.0\end{array}$ & $\begin{array}{c}118 \\
5 \\
2\end{array}$ & $\begin{array}{r}94.2 \\
3.9 \\
1.9\end{array}$ \\
\hline $\begin{array}{l}\text { Which is better as a Vitamin D source; } \\
\text { Powder milk } \\
\text { Breast milk } \\
\text { Both are equal }\end{array}$ & $\begin{array}{r}3 \\
24 \\
0\end{array}$ & $\begin{array}{r}10.0 \\
90.0 \\
0.0\end{array}$ & $\begin{array}{c}112 \\
11 \\
2\end{array}$ & $\begin{array}{l}89.8 \\
8.3 \\
1.9\end{array}$ \\
\hline $\begin{array}{l}\text { Are Pregnant Females susceptible to } \\
\text { vitamin D deficiency? } \\
\text { Yes } \\
\text { No }\end{array}$ & $\begin{array}{r}18 \\
3 \\
\end{array}$ & $\begin{array}{l}70.0 \\
10.0\end{array}$ & $\begin{array}{c}120 \\
3\end{array}$ & $\begin{array}{r}96.1 \\
2.4\end{array}$ \\
\hline $\begin{array}{l}\text { Are girls susceptible to vitamin D } \\
\text { deficiency? } \\
\qquad \begin{array}{l}\text { Yes } \\
\text { No }\end{array}\end{array}$ & $\begin{array}{r}14 \\
6\end{array}$ & $\begin{array}{l}57.3 \\
20.9\end{array}$ & $\begin{array}{c}123 \\
2\end{array}$ & $\begin{array}{r}99.0 \\
1.0\end{array}$ \\
\hline $\begin{array}{l}\text { Why are they susceptible? } \\
\text { Do not exposed to sun } \\
\text { Do not eat fish }\end{array}$ & $\begin{array}{c}18 \\
0\end{array}$ & $\begin{array}{c}70.0 \\
0.0\end{array}$ & $\begin{array}{c}115 \\
5\end{array}$ & $\begin{array}{c}92.6 \\
3.9\end{array}$ \\
\hline
\end{tabular}

* All "do not know" responses were omitted 
Knowledge, Attitudes, and Behavior (KAP) and their impact on Vitamin D Status among Undergraduate University Female Students

Dina IS, Afaf HS, Nefisa HB, and Mohamed MN

Table (5): Frequency Distribution of Participants by their pattern of milk and Dairy products' consumption in relation

to area of descent:

\begin{tabular}{|c|c|c|c|c|c|c|}
\hline \multirow[t]{2}{*}{ Pattern } & \multicolumn{2}{|c|}{$\begin{array}{c}\text { Rural (row } \\
\% \text { ) }\end{array}$} & \multicolumn{2}{|c|}{$\begin{array}{c}\text { Urban (row } \\
\%)\end{array}$} & \multicolumn{2}{|c|}{$\begin{array}{c}\text { Total } \\
\text { (column \%) }\end{array}$} \\
\hline & No & $\%$ & No & $\%$ & No & $\%$ \\
\hline \multirow{4}{*}{$\begin{array}{r}\text { Dairy frequency/day } \\
\text { once } \\
\text { twice }\end{array}$} & & & & & & \\
\hline & 56 & 50.5 & 55 & 49.5 & 111 & 89.5 \\
\hline & 6 & 46.2 & 7 & 53.8 & 13 & 10.5 \\
\hline & \multicolumn{6}{|c|}{$\mathrm{X}^{2}=0.086 \quad \mathrm{p}=1.000$} \\
\hline \multicolumn{7}{|l|}{ Type of Milk Fat } \\
\hline Full milk & 50 & 51.5 & 47 & 48.5 & 97 & 86.6 \\
\hline Partially skimmed & 1 & 11.1 & 8 & 88.9 & 9 & 8.0 \\
\hline \multirow[t]{2}{*}{ Skimmed } & 3 & 50.0 & 3 & 50.0 & 6 & 5.4 \\
\hline & \multicolumn{6}{|c|}{$\mathrm{X}^{2}=6.148 \quad \mathrm{p}=0.067$} \\
\hline \multicolumn{7}{|l|}{ Milk in Main meal } \\
\hline Yes & 17 & 53.1 & 15 & 46.9 & 32 & 28.1 \\
\hline \multirow[t]{2}{*}{ No } & 39 & 47.6 & 43 & 52.4 & 82 & 71.9 \\
\hline & \multicolumn{6}{|c|}{$\mathrm{X}^{2}=2.85 \quad \mathrm{p}=0.678$} \\
\hline \multicolumn{7}{|l|}{ Milk in snacks } \\
\hline Yes & 31 & 47.7 & 34 & 52.3 & 65 & 58.6 \\
\hline \multirow[t]{2}{*}{ No } & 24 & 52.2 & 22 & 47.8 & 46 & 41.4 \\
\hline & \multicolumn{6}{|c|}{$X^{2}=0.216 \quad p=0.702$} \\
\hline \multicolumn{7}{|l|}{ Reason for not consuming milk } \\
\hline Costy & 7 & 70.0 & 3 & 30.0 & 10 & 31.3 \\
\hline \multirow[t]{2}{*}{ Dislike } & 15 & 68.2 & 7 & 31.8 & 22 & 68.7 \\
\hline & \multicolumn{6}{|c|}{$X^{2}=0.011$} \\
\hline
\end{tabular}


Knowledge, Attitudes, and Behavior (KAP) and their impact on Vitamin D Status among Undergraduate University Female Students

Dina IS, Afaf HS, Nefisa HB, and Mohamed MN

Table (6): Average Daily Food Intake presented as Median (IQR)* among participants in relation to number of calcium services per day:

\begin{tabular}{|c|c|c|c|}
\hline Nutrients $(\mathrm{RDA})^{* *}$ & $\begin{array}{c}\text { 1 Ca service } \\
\text { (Up to } 300 \mathrm{mg} \\
\text { /day) }\end{array}$ & $\begin{array}{c}2 \text { Ca services } \\
\text { (> } 300 \text { to } 600 \\
\text { mg/day) }\end{array}$ & $\begin{array}{l}\text { 3 Ca services } \\
\text { (> } 600 \mathrm{mg} / \text { day) }\end{array}$ \\
\hline $\begin{array}{l}\text { Calories } \\
\text { (2200Kcal/day)Median } \\
\text { (IQ) } \\
\quad \text { Min - Max }\end{array}$ & $\begin{array}{l}1322.9(887.0- \\
1635.6) \\
427.5-2559.6\end{array}$ & $\begin{array}{l}1778.6(1411.0- \\
2217.0) \\
807.0-3395.0\end{array}$ & $\begin{array}{l}2134.9(1762.0- \\
2664.5) \\
1497.3-4188.0\end{array}$ \\
\hline $\begin{array}{l}\text { Protein*** } \\
\text { (42.1-50.8 g/day) } \\
\text { Median (IQ) } \\
\text { Min --Max }\end{array}$ & $\begin{array}{l}47.0(37.5-59.0) \\
13.0-121.0\end{array}$ & $\begin{array}{l}70.0(56.4-80.0) \\
31.0-141.0\end{array}$ & $\begin{array}{l}79.6(68.0-102.0) \\
53.0-175.9\end{array}$ \\
\hline $\begin{array}{l}\text { Ca } \\
(1200 \text { mg/day) } \\
\text { Median (IQ) } \\
\text { Min - Max }\end{array}$ & $\begin{array}{l}221.0(142.0- \\
295.3) \\
\quad 64.0-329.0\end{array}$ & $\begin{array}{l}459.0(395.0- \\
578.7) \\
\quad 345.8-665.0\end{array}$ & $\begin{array}{l}794.0(752.9- \\
933.1) \\
\quad 669.0-2221.0\end{array}$ \\
\hline $\begin{array}{l}\text { Pi } \\
(1250 \text { mg/day) } \\
\text { Median (IQ) } \\
\text { Min - Max }\end{array}$ & $\begin{array}{c}540.5(422.0- \\
829.4) \\
168.0-1336.1\end{array}$ & $\begin{array}{c}941.9(808.0- \\
1062.0) \\
466.0-1957.3\end{array}$ & $\begin{array}{l}1064.0(920.2- \\
1389.7) \\
278.0-2293.1\end{array}$ \\
\hline $\begin{array}{lc}\mathrm{Ca} / \mathrm{Pi} & \text { ratio (2:1) } \\
& \text { Median (IQ) } \\
& \text { Min - Max }\end{array}$ & $\begin{array}{c}0.3(0.3-0.5) \\
0.1-0.8\end{array}$ & $\begin{array}{c}0.5(0.4-0.6) \\
0.2-1.1\end{array}$ & $\begin{array}{c}0.7(0.6-0.9) \\
0.4-3.6\end{array}$ \\
\hline $\begin{array}{r}\text { Iron (29-31 mg/day) } \\
\text { Median (IQ) } \\
\text { Min - Max }\end{array}$ & $\begin{array}{c}8.0(6.0-13.5) \\
2.0-30.3\end{array}$ & $\begin{array}{c}12.6(9.0-16.3) \\
4.3-27.0\end{array}$ & $\begin{array}{c}13.4(11.0-18.0) \\
7.0-32.6\end{array}$ \\
\hline $\begin{array}{r}\text { Zinc ( } 8 \text { mg/day) } \\
\text { Median (IQ) } \\
\text { Min - Max }\end{array}$ & $\begin{array}{c}6.0(5.0-8.5) \\
1.0-20.0\end{array}$ & $\begin{array}{c}9.0(7.5-11.0) \\
4.0-23.3\end{array}$ & $\begin{array}{c}11.0(10.0-13.1) \\
8.0-30.6\end{array}$ \\
\hline
\end{tabular}


Knowledge, Attitudes, and Behavior (KAP) and their impact on Vitamin D Status among Undergraduate University Female Students

Dina IS, Afaf HS, Nefisa HB, and Mohamed MN

\section{Table (7): Non-parametric Correlation between Vitamin D status groups and some risky Factors}

\begin{tabular}{|l|c|c|c|}
\hline \multirow{2}{*}{ Risky factors } & \multicolumn{3}{|c|}{ Vitamin D status* } \\
\cline { 2 - 4 } & $\begin{array}{c}\text { Correlation } \\
\text { coefficient }\end{array}$ & $\begin{array}{c}\text { Significance } \\
\text { (1-tailed) }\end{array}$ & No \\
\hline $\begin{array}{l}\text { Season } \\
\text { Spring }\end{array}$ & .32 & .000 & 110 \\
\hline Age & -.28 & .001 & 110 \\
\hline BMI & -.057 & .276 & 110 \\
\hline Waist & -.002 & .49 & 110 \\
\hline Meal No. & -.028 & .386 & 110 \\
\hline Ca services & -.085 & .19 & 109 \\
\hline Milk (full & -.035 & .14 & 110 \\
cream) & -.002 & .36 & 108 \\
\hline Cheese \\
(natural) & & .49 & 108 \\
\hline Fish & .14 & .07 & 108 \\
\hline Egg & -.09 & .17 & 108 \\
\hline Tea/ coffee & -.012 & .17 & 108 \\
\hline Chipsy & -.059 & .27 & 108 \\
\hline Cola & -.047 & .33 & 91 \\
\hline
\end{tabular}

*Vitamin D Status is the classification of laboratory results based on the normal physiological PTH-VD axis using cut-offs of vitamin D, calcium, and phosphorus in relation to cut-offs of PTH. 


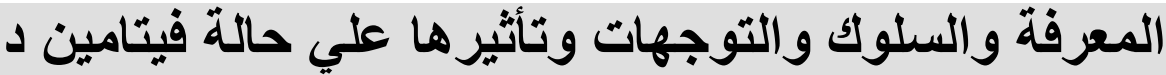

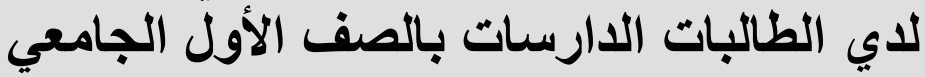

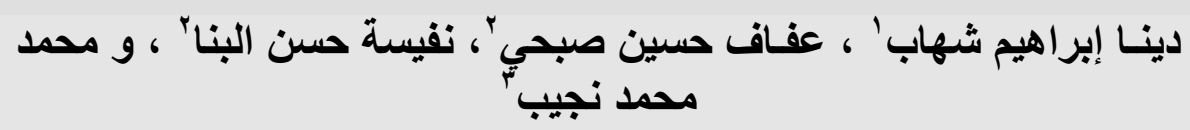

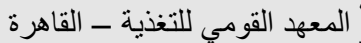

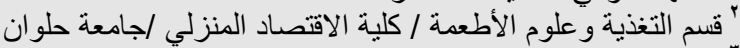

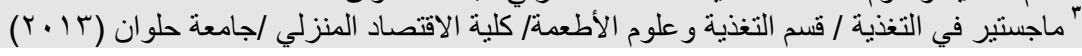

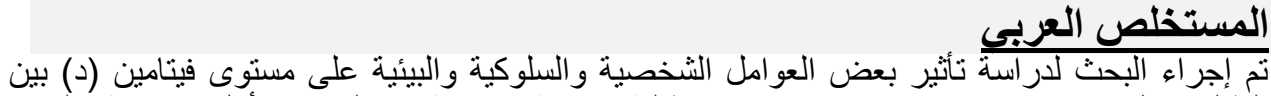

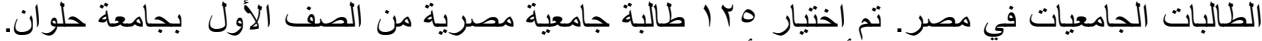

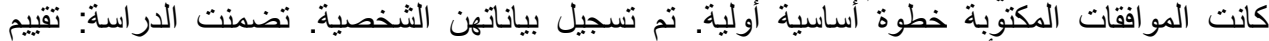

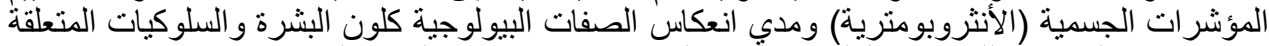

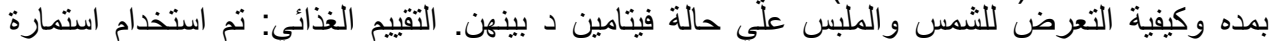

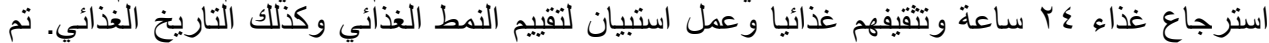

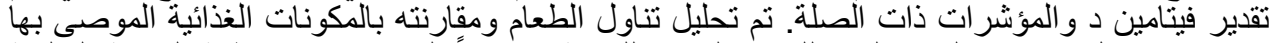

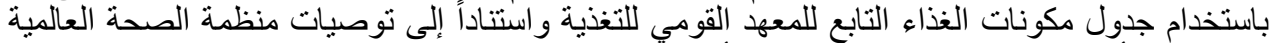

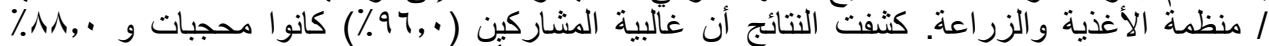

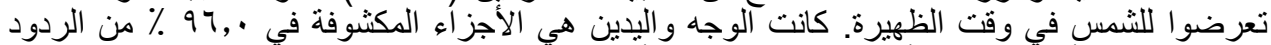

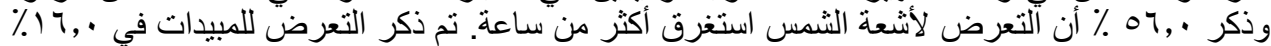

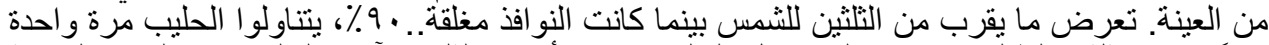

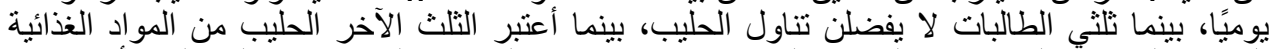

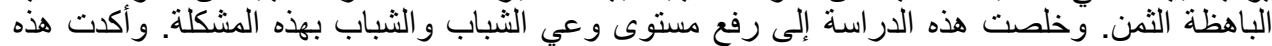

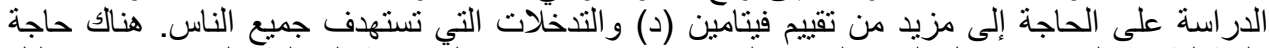

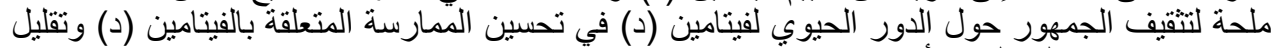
مضاعفات نقصه إلى الحد الأدنى.

الكلمات المفتاحية: الوعي بفيتامين د ، الفتيات بسن المر اهقة ، طالبات الجامعيات 